\title{
The Antioxidant and Antibacterial Activity of Moringa oleifera Extracts against some Foodborne Pathogens
}

\author{
Shaymaa Rajab Farhan ${ }^{1}$, Ahmed H. AL-Azawi ${ }^{2}$, Elham Ismaeel AL-Shamary ${ }^{3}$ \\ ${ }^{1}$ Researcher, Ministry of Science and Technology, ${ }^{2}$ Assistant Professor, Biotechnology Dept., Genetic Engineering \\ and Biotechnology Institute for Post Graduate Studies, University of Baghdad, Baghdad, Iraq, ${ }^{3}$ Professor, Food \\ Science and Biotechnology Dept., College of Agricultural Engineering Sciences, University of Baghdad, Baghdad, \\ Iraq
}

\begin{abstract}
The aim of this study is to determine the antioxidant and antibacterial activity of Moringa oleifera extracts. Maceration and Soxhlet apparatus were used to prepare aqueous and methanolic extracts respectively, while petroleum ether was used to extract seed oil. Many tests were conducted include, phytochemical detection, evaluation of antioxidant activity utilizing 2,2- diphenyl-1-picrylhydrazyl (DPPH) assay, total phenolic content. The extracts of Moringa oleifera were investigated against some foodborne pathogens include Staphylococcus aureus, Bacillus cereus, Escherichia coli and Klebsiella pneumonia. The results of phytochemical test showed the presence of alkaloids, phenols, flavonoids, tannins, saponins and glycosides in aqueous and methanolic leaves extracts. The antioxidant activity showed that the aqueous and methanolic leaves extract was more effective than the seed's husk extract. The radical scavenging capacity $\left(\mathrm{EC}_{50}\right)$ of methanolic and aqueous leaves extract were found to be $(1.6$ and $1.9 \mathrm{mg} / \mathrm{ml})$ respectively, while the EC50 of methanolic and aqueous seed's husk were $(5.1$ and $10 \mathrm{mg} / \mathrm{ml})$ respectively. The antibacterial activity of Moringa oleifera extracts showed the best effect was seen in the aqueous and methanolic leaves extract on Staph. aureus in $200 \mathrm{mg} / \mathrm{ml}$ with inhibition zone 14.83 and $22.6 \mathrm{~mm}$ respectively. The results of the minimum inhibitory concentration (MIC) showed that the methanolic leaves extract was $16 \mathrm{mg} / \mathrm{ml}$ for both Staph. aureus and E. coli, and $32 \mathrm{mg} / \mathrm{ml}$ for B. cereus and K. pneumonia, while the MIC of aqueous leaves extract was $64 \mathrm{mg} / \mathrm{ml}$ for all bacterial isolates.
\end{abstract}

Keywords: Moringa oleifera extracts, antibacterial activity, MIC, DPPH, Total phenol.

\section{Introduction}

Moringa oleifera is a plant belongs to the family moringaceae which consists of one genus moringa ${ }^{1}$. It is a tree with a high value, distributed in many countries of the tropics and subtropics. The tree has different argot names such as marango, moringa, horseradish tree, drumstick tree, miracle tree, tree of life ${ }^{2}$. Almost all parts of the plant are used culturally for its nutritional value, purported medicinal properties and for taste and flavor as a vegetable and seed. The leaves of moringa

Corresponding author:

Ahmed H. AL-Azawi

ahmed@ige.uobaghdad.edu.iq oleifera can be eaten fresh, cooked or stored as dried powder for many months without any major loss of its nutritional value. Epidemiological studies have indicated that moringa oleifera leaves are a good source of nutrition and exhibit anti-tumor, anti-inflammatory, anti-ulcer, anti-atherosclerotic and anti-convulsant activities ${ }^{3}$. The leaves of moringa oleifera are a good source of natural antioxidants due to the presence of different compounds such as ascorbic acid, flavonoids, phenolics and carotinoids. These compounds have the ability to do numerous functions including acting as free radicals scavengers, enzyme inhibitors, reduce damage caused by free radical activity and oxidation ${ }^{4}$. Medicinal plants are a source for a wide variety of natural active compounds and are used for the treatment of diseases 
throughout the world. Several types of plant extracts or plant-derived molecules have been investigated for their potential as antibacterial and antioxidant sources against several diseases $5,6,7$. Thus, main purpose of this research is detection of the active compounds in Moringa oleifera cultivated in Iraq and evaluate the antibacterial activity on some foodborne pathogens.

\section{Materials and Methods}

\section{Collection of Moringa oleifera}

Moringa oleifera seeds and leaves were obtained from the plantation of Al-Diwaniyah city, Iraq. The plant materials were botanically identified by the Laboratory of College of Science of the University of Baghdad. The leaves were washed with water and dried at room temperature, and ground using a grinder, and then stored at $4^{\circ} \mathrm{C}$ for further analysis. The seeds were shelled by using mortar and pestle. The husk and kernel were ground separately to a fine powder and stored at $4^{\circ} \mathrm{C}$ for further analysis.

\section{Preparation of aqueous extract}

The aqueous extract was prepared according to ${ }^{8}$. Macerated 100 gram of Moringa oleifera leaves in 700 $\mathrm{ml}$ of distilled water for 72 hours, after extraction, the mixture was vacuum filtered through Whitman No. 1 paper. The filtrate evaporated to dryness under vacuum at $50^{\circ} \mathrm{C}$ by a rotary evaporator to eliminate water. The resulting extract stored in amber glass vials at $4{ }^{\circ} \mathrm{C}$ until analyzed.

\section{Preparation of methanolic extract}

Methanolic extract was prepared according to 9 , using Soxhelt apparatus. 100 gram of Moringa oleifera leaves was put in a thimble and $350 \mathrm{ml}$ of $70 \%$ methanol was added within $40-60{ }^{\circ} \mathrm{C}$ for 6 hours. The solution was filtered through a filter paper Whitman No.1 and evaporated to dryness under vacuum at $40^{\circ} \mathrm{C}$ by a rotary evaporator to get rid of methanol; the extract was stored in amber glass vials at $4{ }^{\circ} \mathrm{C}$ until analyzed.

\section{Phytochemical screening}

The phytochemical screening of the aqueous and methanolic leaves and seed extracts has been done according to $10,11,12,13,14$.

\section{Evaluation of the Antioxidant activity DPPH} assay

The radical scavenging activity of samples was determined according to ${ }^{15} .5 \mathrm{ml}$ of a freshly prepared $0.004 \%$ of 2,2-diphenyl-1-picrylhydrazyl (DPPH) in methanol was mixed with $100 \mu$ of different concentrations $(2,4,6,8$ and 10$) \mathrm{mg} / \mathrm{ml}$ of the methanolic and aqueous leaves and seeds extracts, and (20, 40, 60, 80 and 100) $\mu \mathrm{I} \backslash \mathrm{ml}$ of the seed oil extract, then the mixture was left to stand for $30 \mathrm{~min}$. The absorbance was measured at $517 \mathrm{~nm}$. Butylated hydroxytoluene (BHT) (artificial antioxidant) and vitamin C (natural antioxidant) were used as positive control. All tests were performed in triplicate. The percentage of DPPH reduction was calculated as:

$$
\% \text { Reduction }=(\text { Abs DPPH }- \text { Abs Dil. }) / A b s \text { DPPH }
$$
$\times 100$

Where:

Abs DPPH $=$ average absorption of the DPPH solution

Abs Dil. $=$ average absorption of the three absorption values of each dilution.

With the obtained values, a graphic was made using Microsoft Excel. The $\mathrm{EC}_{50}$ of each extract (concentration of extract or compound at which reduced $50 \%$ of DPPH) was taken from the graphic.

\section{Determination of total phenolic contents}

Total phenolic content of Moringa oleifera extracts were determined spectrophotometrically using the FolinCiocalteu method described by ${ }^{16} .2 \mathrm{ml}$ of Folin-Ciocalteu reagent (diluted 10 times) was mixed with $1.6 \mathrm{ml}$ of $7.5 \%$ sodium carbonate solution and $0.4 \mathrm{ml}$ of Moringa oleifera extracts. The volume was completed to $5 \mathrm{ml}$ by adding distilled water. The tubes were covered with parafilm for $30 \mathrm{~min}$. at room temperature, and then the absorbance was read at $760 \mathrm{~nm}$ spectrophotometrically.

\section{Bacterial isolates}

Bacilluscereus, Staphylococcus aureus, Escherichia 
coli and Klebsiella peneumoniae isolated from food, obtained from the Department of Food Sciences-College of Agricultural Engineering Sciences- University of Baghdad, and emphasize diagnoses by using VITEK-2 System.

\section{Agar well diffusion method}

Agar well diffusion method was employed for the determination of this study. Muller- Hinton agar plates were swabbed (sterile cotton swabs) with broth culture of respective bacteria. Wells $6 \mathrm{~mm}$ diameter was made in each of these plates using a sterile cork borer. 100 $\mu \mathrm{l}$ from each concentration $(50,100$ and $200 \mathrm{mg} / \mathrm{ml})$ of the methanolic and aqueous leaves and seeds extracts and $(125,250$ and $500 \mu \mathrm{l} / \mathrm{ml})$ of the seed oil extract were put in each hole by using micropipette and allowed to diffuse at room temperature for $30 \mathrm{~min}$. The plates were incubated at $37^{\circ} \mathrm{C}$ for $18-24$ hours. All tests were performed in triplicate. The diameter of any resulting zone of inhibition was measured in millimeters ${ }^{17}$.

\section{Determination of the minimum inhibitory concentration (MIC) of the Moringa oleifera extracts}

Broth Microdilution method was used to determine the MIC of Moringa oleifera extracts using the 96-well microtiter plate. The extracts were prepared in a double concentration, the desired final concentration as it will be diluted with an equal amount of bacteria in broth. 200 $\mu l$ of the prepared methanolic and aqueous extracts (for leaves and seeds) were introduced into the first wells in columns 1-4 (in row A). Rows B-H in columns 1-4 had $100 \mu 1$ of broth alone while rows A-H in column 5 had $100 \mu \mathrm{l}$ of the broth only, and $100 \mu \mathrm{l}$ of broth was in A-H in column 6. Twofold serial dilutions using micropipette was done systematically down the columns 1-4 (from rows B-H). $100 \mu \mathrm{l}$ was removed from the starting concentrations (columns 1-4 in row A) and transferred to the next row with the $100 \mu 1$ broth, properly mixed, and the procedure was repeated up to the last row $(\mathrm{H})$ where the last $100 \mu 1$ was discarded. This brings the final volume in all the test wells with the extracts to $100 \mu$ l except the $6^{\text {th }}$ column which had $200 \mu 1$ of the broth that served as sterility control. $100 \mu \mathrm{l}$ of the $1 \times 10^{6} \mathrm{CFU} / \mathrm{ml}$ bacterial inoculum was transferred into all the wells except the $6^{\text {th }}$ column to give us the desired final inoculum load of $5 \times 10^{5} \mathrm{CFU} / \mathrm{ml}$. Column 5 served as positive control (bacteria- free). Microtiter plates were incubated at $37^{\circ} \mathrm{C}$ for $18-20 \mathrm{hrs}$. After incubation, $20 \mu \mathrm{l}$ of resazurin dye was added to all the wells and incubated for some minutes to observe any color changes. The Minimum Inhibitory Concentrations were determined visually in broth microdilution as the lowest concentrations of the extracts at which color changed from blue to pink in the resazurin broth assay ${ }^{18}$.

\section{Statistical Analysis}

The Statistical Analysis System was used to detect the effect of difference factors in study parameters. Least significant difference-LSD test was used to significant compare between means in this study ${ }^{19}$.

\section{Results and Discussion}

Phytochemical characterizations of methanolic and aqueous (seed's husk and leaves) of Moringa oleifera extracts were subjected to different chemical tests for the detection of different phyto-constituents. Table 1 show the phytochemicals presence in Moringa oleifera extracts. These results agreed with Shanmugavel et al. ${ }^{20}$ they reported the presence of alkaloids, tannins saponins, flavonoids and glycosides in methanolic extract of Moringa oleifera leaves. 
Table 1: Phytochemical screening of moringa oleifera leaves and seed's husk extracts

\begin{tabular}{|c|c|c|c|c|c|}
\hline \multirow{2}{*}{ Phytochemical compound } & \multicolumn{2}{|c|}{ leaves extracts } & \multicolumn{2}{c|}{ seed's husk extracts } \\
\cline { 3 - 6 } \multicolumn{2}{|c|}{} & $\begin{array}{c}\text { Aqueous } \\
\text { Extract }\end{array}$ & $\begin{array}{c}\text { Methanolic } \\
\text { Extract }\end{array}$ & $\begin{array}{c}\text { Aqueous } \\
\text { Extract }\end{array}$ & $\begin{array}{c}\text { Methanolic } \\
\text { Extract }\end{array}$ \\
\hline \multirow{2}{*}{ Alkaloids } & Meyer's test & + & + & + & + \\
\cline { 2 - 6 } & Wagner's reagent & + & + & + & + \\
\hline \multirow{2}{*}{ phenols } & Lead acetate & + & + & + & - \\
\cline { 2 - 6 } & Ferric chloride & + & + & + & - \\
\cline { 2 - 6 } & Fead acetate & + & + & + & + \\
\hline \multicolumn{2}{|c|}{ Saponins chloride } & + & + & + & + \\
\hline \multicolumn{2}{|c|}{ Flavonoids } & + & + & - & - \\
\hline \multicolumn{2}{|c|}{ Glycosides } & + & + & - & - \\
\hline
\end{tabular}

\section{DPPH assay}

Moringa oleifera extracts had free radical scavenging activity; this was evident in a concentration-dependent manner with significant differences $(\mathrm{P} \leq 0.05)$ between concentrations, and the results revealed that the leaves extracts were more effective than seed's husk extracts extract in free radical scavenging activity as shown in Table 2.
Charoensin ${ }^{21}$ study the antioxidant activity of Moringa oleifera leaves using (DPPH) assay. Fitriana et al. ${ }^{22}$ revealed that the methanolic extract of Moringa oleifera leaves had the highest free radical scavenging activity compared to ethyl acetate, n-hexane and dichloromethane extracts. Furthermore, El-Hadary and Ramadan 23 in their study of antioxidant traits of Moringa oleifera leaves extracts referred to the scavenging activity of aqueous leaves extract which was $79.13 \pm 0.28$.

Table 2: Radical scavenging activity of moringa oleifera leaves extracts

\begin{tabular}{|c|c|c|c|c|c|c|}
\hline \multirow{2}{*}{$\begin{array}{c}\text { Concentration } \\
\text { mg } \backslash \mathrm{ml}\end{array}$} & \multicolumn{2}{|c|}{ Leaves extracts } & \multicolumn{2}{|c|}{ seed's husk extracts } & \multirow[b]{2}{*}{ BHT } & \multirow[b]{2}{*}{ V.C. } \\
\hline & $\begin{array}{c}\text { Aqueous } \\
\text { extract }\end{array}$ & $\begin{array}{c}\text { Methanolic } \\
\text { extract }\end{array}$ & $\begin{array}{c}\text { Aqueous } \\
\text { extract }\end{array}$ & $\begin{array}{c}\text { Methanolic } \\
\text { extract }\end{array}$ & & \\
\hline 2 & $56.10 \pm 0.08$ & $64.27 \pm 0.06$ & $17.25 \pm 0.16$ & $37.83 \pm 0.03$ & $88.48 \pm 0.02$ & $93.44 \pm 0.04$ \\
\hline 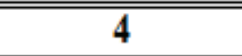 & $66.17 \pm 0.14$ & $86.95 \pm 0.06$ & $18.10 \pm 0.01$ & $43.57 \pm 0.03$ & $89.14 \pm 0.01$ & $93.57 \pm 0.01$ \\
\hline "6 & $83.40 \pm 0.01$ & $90.83 \pm 0.02$ & $28.33 \pm 0.01$ & $54.29 \pm 0.18$ & $91.40 \pm 0.01$ & $96.08 \pm 0.02$ \\
\hline 8 & $86.26 \pm 0.19$ & $91.40 \pm 0.01$ & $40.59 \pm 0.03$ & $57.98 \pm 0.27$ & $91.47 \pm 0.01$ & $96.27 \pm 0.02$ \\
\hline 10 & $87.33 \pm 0.03$ & $92.88 \pm 0.07$ & $50.25 \pm 0.06$ & $63.47 \pm 0.06$ & $92.76 \pm 0.03$ & $96.34 \pm 0.02$ \\
\hline LSD value & $0.353 *$ & $0.154^{*}$ & $0.254 *$ & $0.472 *$ & $0.053 *$ & $0.067 *$ \\
\hline
\end{tabular}

* $(\mathrm{P} \leq 0.05)$

Total phenolic content of Moringa oleifera extracts

The results of the total phenolic content of Moringa oleifera extracts as shown in Table 3. The methanolic extract in both leaves and seed's husk had the highest total phenolic content which was (73.71 and 63.30) in 50 $\mathrm{mg} / \mathrm{ml}$ respectively. The results were in agreement with Vyas et al. ${ }^{24}$ which referred that the highest total phenolic content of Moringa oleifera was for leaves extracted by methanol, compared to other parts. Furthermore, Karim 
et al. ${ }^{25}$ mention, the low total phenolic content of aqueous leaves extract, which was $5.57 \mathrm{mg} / \mathrm{g}$.

Table 3: Total phenolic content of moringa oleifera leaves extracts

\begin{tabular}{|c|c|c|c|c|}
\hline \multirow{2}{*}{$\begin{array}{c}\text { Concentration } \\
(\mathrm{mg} \backslash \mathrm{ml})\end{array}$} & \multicolumn{2}{|c|}{ Moringa oleifera leaves extracts } & \multicolumn{2}{|c|}{ seed's husk extracts } \\
\hline & $\begin{array}{c}\text { Methanolic } \\
\text { extract }(\mathbf{m g} \mid \mathrm{g})\end{array}$ & $\begin{array}{c}\text { Aqueous extract } \\
\text { (mg } \mid \mathrm{g})\end{array}$ & $\begin{array}{c}\text { Methanolic } \\
\text { extract (mg\g) }\end{array}$ & $\begin{array}{c}\text { Aqueous extract } \\
\text { (mg|g) }\end{array}$ \\
\hline 10 & $42.34 \pm 0.24$ & $25.31 \pm 0.35$ & $18.11 \pm 0.11$ & $13.67 \pm 0.03$ \\
\hline 25 & $62.89 \pm 0.12$ & $50.11 \pm 0.12$ & $42.77 \pm 0.15$ & $26.92 \pm 0.26$ \\
\hline 50 & $73.71 \pm 0.14$ & $61.59 \pm 0.18$ & $63.30 \pm 0.2$ & $47.34 \pm 0 . .02$ \\
\hline LSD value & $0.613^{*}$ & $0.827 *$ & $0.571 *$ & $0.529 *$ \\
\hline
\end{tabular}

* $(\mathrm{P} \leq 0.05)$

Antibacterial activity of Moringa oleifera extracts

Agar well diffusion method was used to evaluate the antibacterial activity of Moringa oleifera extracts against two gram positive bacteria (Staphylococcus aureus and Bacillus cereus) and two gram negative bacteria (Escherichia coli and Klebsiella pneumonia). The results were listed in Tables 4 and 5. For the methanolic leaves extract, all concentrations were found to be active against all tested bacteria. The maximum antibacterial activity was observed on Staph. aureus with inhibition zone $22.66 \pm 0.66 \mathrm{~mm}$ in concentration $(200 \mathrm{mg} / \mathrm{ml})$, while the methanolic seed's husk extract showed there was no inhibition zone at concentration 50 $\mathrm{mg} / \mathrm{ml}$ in all tested isolates. The highest effect was seen on Staph. aureus with the inhibition zone $(9.83 \pm 0.16$ $\mathrm{mm}$ and $14.83 \pm 0.16 \mathrm{~mm})$ in concentrations $(100 \mathrm{mg} / \mathrm{ml}$ and $200 \mathrm{mg} / \mathrm{ml}$ ) respectively, followed by E. coli and K. pneumonia $(12.66 \pm 0.33$ and $14.33 \pm 0.33 \mathrm{~mm})$ in concentrations $(200 \mathrm{mg} / \mathrm{ml})$ respectively.

The result was agreement with a study by Abdallah et al ${ }^{26}$ which referred to the high inhibitory effects of methanolic leaves extracts of Moringa oleifera on $S$. aureus and K. pneumonia and the water extract of leaves at concentration $200 \mathrm{mg} / \mathrm{ml}$ had the lowest effect on the gram negative bacteria. Furthermore Yetunde and Comfort ${ }^{27}$ mentioned that the aqueous extract of Moringa oleifera leaves at concentrations 50, 100 and $200 \mathrm{mg} / \mathrm{ml}$ did not show any inhibitory effect on $B$. cereus, E. coli and Staph. aureus. In contrast, Singh and Tafida ${ }^{28}$ refer to the significant high antibacterial activity of aqueous and methanolic extracts of Moringa oleifera leaves on E. coli which were $7.33+0.57 \mathrm{~mm}$ and $8.67+0.57 \mathrm{~mm}$ respectively compared to Staph. aureus and Pseudomonas aeruginosa.

Table 4: Antibacterial activity of moringa oleifera leaves extract

\begin{tabular}{||c|c|c|c|c||}
\hline \multicolumn{5}{|c|}{ Methanolic leaves extract } \\
\hline $\begin{array}{c}\text { Concentration } \\
(\mathbf{m g} / \mathbf{m l})\end{array}$ & Staph. aureus & Bacillus cereus & E. coli & K. pneumoniae \\
\hline \hline $\mathbf{5 0}$ & $7.83 \pm 0.16$ & $6.16 \pm 0.16$ & $7.33 \pm 0.33$ & $8.83 \pm 0.16$ \\
\hline \hline $\mathbf{1 0 0}$ & $15.66 \pm 0.33$ & $12.66 \pm 0.33$ & $14.16 \pm 0.16$ & $14.66 \pm 0.33$ \\
\hline \hline $\mathbf{2 0 0}$ & $22.66 \pm 0.66$ & $17.66 \pm 0.33$ & $20.00 \pm 0.57$ & $20.33 \pm 0.33$ \\
\hline \hline LSD value & $1.338^{*}$ & $1.095^{*}$ & $2.066^{*}$ & $1.169 *$ \\
\hline \hline \multicolumn{5}{|c||}{ Aqueous leaves extract } \\
\hline \hline $\mathbf{5 0}$ & $0.00 \pm 0.00$ & $0.00 \pm 0.00$ & $0.00 \pm 0.00$ & $0.00 \pm 0.00$ \\
\hline \hline $\mathbf{1 0 0}$ & $8.83 \pm 0.16$ & $5.66 \pm 0.33$ & $5.83 \pm 0.16$ & $8.66 \pm 0.33$ \\
\hline \hline $\mathbf{2 0 0}$ & $14.83 \pm 0.16$ & $12.66 \pm 0.66$ & $13.00 \pm 0.57$ & $14.66 \pm 0.33$ \\
\hline LSD value & $1.239^{*}$ & $0.966^{*}$ & $0.902 *$ & $1.317 *$ \\
\hline (P $\leq \mathbf{0 . 0 5})$ & &
\end{tabular}


Table 5: Antibacterial activity of moringa oleifera seed's husk extract

\begin{tabular}{||c|c|c|c|c||}
\hline \multicolumn{5}{|c|}{ Methanolic seed's husk extract } \\
\hline \hline $\begin{array}{c}\text { Concentration } \\
(\mathbf{m g} / \mathbf{m l})\end{array}$ & Staph. aureus & Bacillus cereus & E. coli & K. pneumoniae \\
\hline \hline $\mathbf{5 0}$ & $0.00 \pm 0.00$ & $0.00 \pm 0.00$ & $0.00 \pm 0.00$ & $0.00 \pm 0.00$ \\
\hline \hline $\mathbf{1 0 0}$ & $9.83 \pm 0.16$ & $6.83 \pm 0.16$ & $8.16 \pm 0.16$ & $8.66 \pm 0.33$ \\
\hline \hline $\mathbf{2 0 0}$ & $14.83 \pm 0.16$ & $9.66 \pm 0.33$ & $12.66 \pm 0.33$ & $14.33 \pm 0.33$ \\
\hline \hline LSD value & $1.255^{*}$ & $0.863^{*}$ & $1.147^{*}$ & $2.168^{*}$ \\
\hline \hline \multicolumn{5}{|c||}{ Aqueous seed's husk extract } \\
\hline \hline $\mathbf{5 0}$ & $0.00 \pm 0.00$ & $0.00 \pm 0.00$ & $0.00 \pm 0.00$ & $0.00 \pm 0.00$ \\
\hline \hline $\mathbf{1 0 0}$ & $0.00 \pm 0.00$ & $0.00 \pm 0.00$ & $0.00 \pm 0.00$ & $0.00 \pm 0.00$ \\
\hline \hline $\mathbf{2 0 0}$ & $9.50 \pm 0.28$ & $7.16 \pm 0.16$ & $8.16 \pm 0.16$ & $9.16 \pm 0.16$ \\
\hline \hline
\end{tabular}

* $(\mathrm{P} \leq 0.05)$

\section{Minimum Inhibitory Concentration (MIC)}

The Minimum Inhibitory Concentration (MIC) of Moringaoleifera extracts was showninFigure 1. Amethod using the oxidation-reduction colorimetric indicator resazurin has been proposed for the determination of drug resistance and MIC of antimicrobial agents against pathogenic organisms ${ }^{29}$. The results of leaves extract showed that the MIC values of methanolic extract were $16 \mathrm{mg} / \mathrm{ml}$ for both Staph. aureus and E. coli, and $32 \mathrm{mg} /$ $\mathrm{ml}$ for $B$. cereus and $K$. pneumonia, while the MIC of aqueous extract was $64 \mathrm{mg} / \mathrm{ml}$ for all bacterial isolates. For seed's husk extracts, the result showed that the MIC of methanolic and aqueous extracts was 64 and $128 \mathrm{mg} /$ $\mathrm{ml}$ respectively for each bacterial isolate.

Phenolic compounds of plants are of noticeable interest due to their antioxidant and antibacterial properties ${ }^{30}$. The means by which microorganisms are inhibited by phenolic compounds involves a sensitization of the phospholipids bilayer of the cell membrane, causing an increase in permeability and leakage of vital intracellular constituents, or impairment of bacterial enzyme systems. Phenolic compounds act by inhibiting the amino acid decarboxylase in target bacteria ${ }^{31}$.

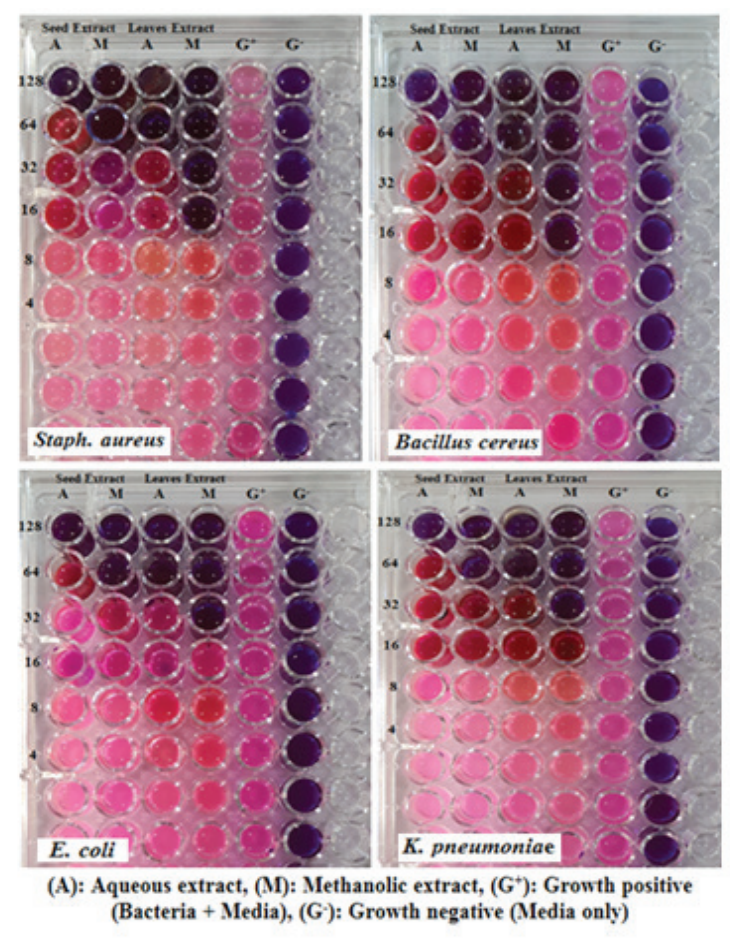

Figure 1: MIC of moringa oleifera leaves and seed's husk extracts

\section{Conclusion}

Moringa oleifera extracts have a wide variety of phytochemicals that show effectiveness against different diseases and The methanolic leaves extract of Moringa oleifera shows relatively a higher amount of phenolic compounds and have equal antioxidant activity to the synthetic antioxidant (BHT) moreover Different Moringa oleifera extracts have a potential antimicrobial 
agent against both gram positive bacteria (Staph. aureus and $B$. cereus) and gram negative bacteria (E. coli and $K$. pneumonia). The methanolic leaves extract has the largest effects against foodborne pathogen used in this study.

Conflict of Interest: The authors declared that present study was performed in absence of any conflict of interest.

\section{Source of Funding: Self}

Ethical Clearance: Not required

\section{References}

1. Ramachandran C, Peter KV, Gopalakrishnan PK. Drumstick (moringa oleifera): A multipurpose Indian vegetable. Econ. Bot. 1980; 34: 276-283.

2. Anwar F, Latif S, Ashraf M, Gilani A. Moringa oleifera: a food plant with multiple medicinal uses. Phytother. Res. 2007; 1(21):17-25.

3. Asghari G, Palizban A, Bakhshaei B. Quantitative analysis of the nutritional components in leaves and seeds of the Persian Moringa peregrine (Forssk.) Fiori. Pharmacognosy Reserch. 2015; 7(3): 242248.

4. Ruttarattanamongkol K, Petrasch A. Antimicrobial activities of Moringa oleifera seed and seed oil residue and oxidative stability of its cold pressed oil compared with extra virgin olive oil. Songklanakarin J. Sci. Technol. 2015; 37(5): 587594.

5. Madaleno IM. Traditional medicinal knowledge in India and Malaysia. Pharmacogn Commun. 2015; 5(2): 116-129.

6. Yasin SA, Al-Azawi AH. Antibacterial activity of Conocarpus erectus leaves extracts on some microorganisms isolated from patients with burn infection. Plant Archives. 2019; 19(2), 583-589.

7. AL-Azawi AH. Phytochemical, Antibacterial and Antioxidant Activities of dodonea viscosa Jacq. extracts Cultivated in Iraq. Iraqi Journal of Biotechnology. 2017; 16 (4): 37-46.

8. N'Guessan JD, Bidie AP, Lenta BN, Weniger B, Andre P, Guina F. In vitro assays for bioactivityguided isolation of anti-salmonella and antioxidant compounds in Thon ninja sanguine flowers. Afr. J. Bio .2007; 6: 1685-1689.

9. American Association of Cereal Chemists (AACC). Method 08-01. The Association St. Paul MN.1984.

10. Harborne, JB. Pytochemical methods. Aguide to modern techniques of plant analysis. $3^{\text {rd }}$ Edition, Chapman and hall: London.1998.

11. Smolensk SJ, Silnis H, Earnsworth NR. Alkaloid screening. VI. Liydia 1972; 35 (1): 31-34.

12. Shihata IM. A pharmacologicalstudy of Anagallis arvensis. M.D. Vet. Thesis. Cairo University.1951.

13. Harborne JB. Phytochemical Methods. Chapman and Hall. London.1984.

14. Jaffer HJ, Mahmod MJ, Jawad AM, Naji A, AlNaib A. Phytochemical and biological screening of some Iraqi plants. Fitot. 1988; 59: 229-233.

15. Kedare SB, Singh RP. Genesis and development of DPPH method of antioxidant assay. J. of Food Sci. and Tech. 2011; 48(4): 412-422.

16. Jayaprakasha GK, Singh RP, Sakariah KK. Antioxidant activity of grape seeds (Vitis vinifera). Food Chem. 2001; 73:285-290.

17. Valgas C, de Souza SM, Smania EFA, Smania A. Screening methods to determine antibacterial activity of natural products. Braz. J. Microbiol. 2007; 38: 369-380.

18. Ohikhena FU, Wintola OA, Afolayan AJ. Evaluation of the Antibacterial and Antifungal Properties of Phragmanthera capitata (Sprengel) Balle (Loranthaceae), a Mistletoe Growing on Rubber Tree, Using the Dilution Techniques. The Scientific World Journal. 2017; Volum 2017. Article ID 9658598. https://doi. org/10.1155/2017/9658598.

19. SAS. Statistical Analysis System, User's Guide. Statistical. Version $9.1^{\text {th }}$ ed. SAS. Inst. Inc. Cary. N.C. USA.2012.

20. Shanmugavel G, Prabakaran K, George B. Evaluation of phytochemical constituents of Moringa oleifera (LAM.) leaves collected from puducherry region, south Indua. International Journal of Zoology and Applied Biosciences. 2018; 1(3): 1-8. 
21. Charoensin S. Antioxidant and anticancer activities of Moringa oleifera leaves. Journal of Medicinal Plant Research. 2014; 8(7): 318-325.

22. Fitriana WD, Ersam T, Shimizu K, Fatmawati S. Antioxidant activity of Moringa oleifera extracts. Indones. J. Chem. 2016; 16(3): 297-301.

23. El-Hadary AE, Ramadan MF. Antioxidant traits and protective impact of Moringa oleifera leaf extract against diclofenac sodium-induced liver toxicity in rats. J. Food Biochem. 2018; 1-9.

24. Vyas S, Kachhwaha S, Kothari SL .Comparative analysis of phenolic contents and total antioxidant capacity of Moringa oleifera Lam. Pharmacognosy Journal. 2015; 1(7): 44-51.

25. Karim N U, Siddiq U S, Razak MR., Zainol MK, Abdullah MI. Effects of moringa leaves (Moringa oleifera) extraction on quality changes and melanosis of giant freshwater prawn (Macrobrachium rosenbergii) during chilled storage. Italian Journal of Food Safety. 2018; 7: 6846.

26. Abdallah AM, Alwasilah HY, Mahjoub RA, Mohammed HI, Yagoub M. Evaluation of antimicrobial activity of Moringa oleifera leaf extracts against pathogenic bacteria isolated from urinary tract infected patients. Journal of Advanced Laboratory Research in Biology. 2016; 2(7): 47-51.

27. Yetunde EA, Comfort US. Antimicrobial activity of Moringa oleifera leaf against isolates of beef offal. British Microbiology Research Journal. 2015; 9(2): 1-7.

28. Singh K, Tafida GM. Antibacterial activity of Moringa oleifera (Lam) leaves extracts against some selected bacteria. International Journal of Pharmacy and Pharmaceutical Sciences. 2013; 9(6): 52-45.

29. Ncube NS, Afolayan AJ, Okoh AI. Assessment techniques of antimicrobial properties of natural compounds of plant origin: current methods and future trends. African Journal of Biotechnology. 2008; 12(7): 1797-1806.

30. Pezeshk S, Ojagh SM, Alishahi A. Effect of plant antioxidant and antimicrobial compounds on the shelf-life of seafood- A review. Czech J. Food Sci. 2015; 33(3): 195-203.

31. Ojagh SM, Rezaei M, Razavi SH, Hosseini SMH. Effect of chitosan coatings enriched with cinnamon oil on the quality of refrigerated rainbow trout. Food Chemistry, 2010; 120: 193-198. 